EESTI NSV TEADUSTE AKADEEMIA TOIMETISED. 27. KOIDE

KEEMIA, 1978, NR. 3

ИЗВЕСТИЯ АКАДЕМИИ НАУК ЭСТОНСКОИ ССР. ТОМ 27 ХИМИЯ. 1978, № 3

Хилья ТААЛ, Айме СЮГИС-РУЛЛИ, Х. ПАЛМРЕ

удК 548.32

\title{
О ДЕРИВАТОГРАММАХ ГОРЮЧЕГО СЛАНЦА КУКЕРСИТА
}

Hilja TAAL, Aime SUGIS-RULLI, H. PALMRE. KUKERSIITPOLEVKIVI DERIVATOGRAMMIDEST Hilja TAAL, Aime SOGIS-RULLI, H. PALMRE. DERIVATOGRAMMES OF OIL SHALE KUKERSITE

Определением вещественного состава сланца-кукерсита занимались многие авторы, применяя химический, минерало-петрографический и термический анализы $\left[{ }^{1-3}\right]$.

Термическое исследование разложения кукерсита проводилось при различных условиях: без доступа кислорода воздуха $\left[{ }^{2,3}\right]$ и в воздушной атмосфере [4]. В первом случае разложение органического вещества (OB) горючего сланца представляет собой эндотермический процесс, во втором случае происходит окисление горючего сланца - экзотермический процесс.

Нами изучена возможность определения состава кукерсита (гигроскопической воды, ОВ, карбонатного $\mathrm{CO}_{2}$ ) при помощи дериватограмм, используя кривые дифференциально-термического анализа (ДТА) и кривые термогравиметрии (ТГ). Для проведения опытов применялся технологический отсев сланца Сланцеперерабатывающего комбината «КохтлаЯрве» им. В. И. Ленина и его флотационные продукты, полученные в Институте химии АН ЭССР.

Исследование проводилось на венгерском дериватографе ОД-102 с навесками в 450 мг, распределенными равномерно на пяти платиновых тарелочках, в слабом токе воздуха при скорости нагрева $10^{\circ} \mathrm{C} /$ мин. В качестве эталонного и разбавляющего вещества использовался предварительно прокаленный при $1200^{\circ} \mathrm{Al}_{2} \mathrm{O}_{3}$ (оч).

Всем дифференциально-термическим эффектам (ДТА) горючего сланца соответствуют определенные потери веса (ТГ), по которым определяли количественное содержание гигроскопической воды, ОВ, карбонатного $\mathrm{CO}_{2}$.

При температуре $123^{\circ}$ (рисунок, $A, B$, кривая ДТА) на кривой ТГ зафиксированы потери веса кукерсита и флотационного остатка, которые, вероятно, принадлежат гигроскопической воде минеральных образований. Сильные экзотермические эффекты на кривых ДТА кукерсита и флотационного концентрата (рисунок, $A, Б$ ) показывают, что разложение ОВ в атмосфере воздуха в интервале температур 200-480 происходит по двум ярко выраженным ступеням, что отличается от ранее известных данных [4], где в том же температурном диапазоне имеется один расплывчатый максимум. Явно выраженные экзотермические эффекты возникают благодаря хорошему доступу воздуха к равномерно распределенному тонкому слою материала, Инфракрасные спектры про- 


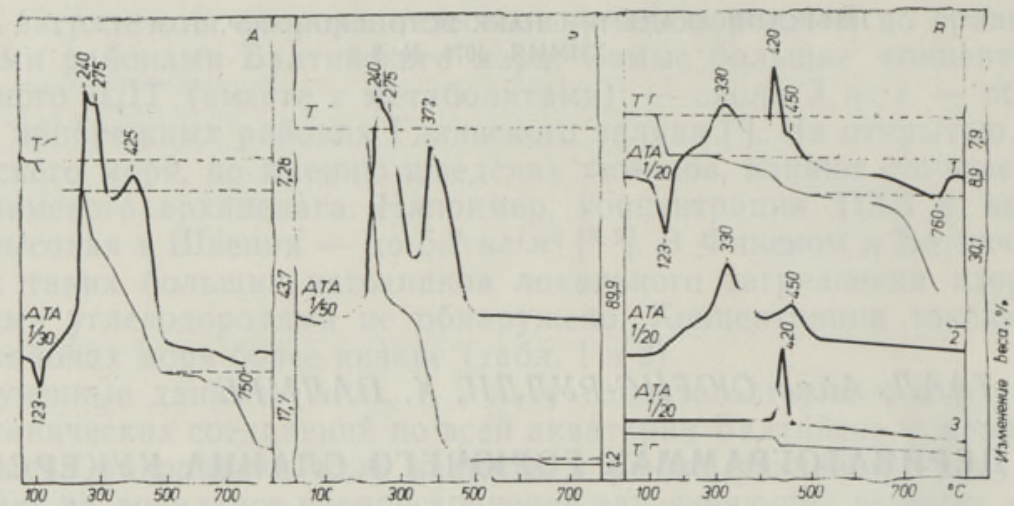

Дериватограммы: $A-$ кукерсита; $D$ - флотационного конщентрата; $B$ - флотационного остатка (1); $\mathrm{Al}_{2} \mathrm{O}_{3}$, содержащего $6,7 \%$ флотационного концентрата (2); $\mathrm{Al}_{2} \mathrm{O}_{3}$, содержащего $6 \%$ пирита (3).

дуктов термического анализа при $340^{\circ}$ (между двумя экзоэффектами) позволяют в некоторой мере объяснить экзотермические эффекты ДТА процесса окисления ОВ. После первого экзотермического пика $\left(275^{\circ}\right)$ ОВ (рисунок, $A, E)$ в ИК-спектрах поглощения исчезают колебания гидроксильных групп и алифатных групп типа $\mathrm{CH}_{2}$. Остаток OB, вероятно, состоит из малореакционного кокса. На кривой ДТА флотационного остатка в этом же температурном интервале имеет место экзотермический эффект с максимумом при $420^{\circ}$ (рисунок, $B$, кривая 1 ). Этот эффект не принадлежит ни окислению ОВ (рисунок, $B$, кривая 2), ни флотореагентам, так как аналогичная дериватограмма получается и при разложении песков гидроциклонирования с почти таким же содержанием ОВ и не содержащих флотореагентов. Известно, что кукерсит содержит пирит ['], который при малых концентрациях дает экзотермический эффект (рисунок, $B$, кривая 3 ) в том же интервале температур. При небольших количествах ОВ горючего сланца можно определить содержание ОВ сравниванием энтальпии по ДТА процессов окисления пирита и флотационного концентрата, соответственно разбавленных $\mathrm{Al}_{2} \mathrm{O}_{3}$, с процессом окисления ОВ в исследуемом материале (рисунок, $B$ ).

Полученные данные содержания ОВ кукерсита подтверждаются результатами, полученными при определении по удельному весу, в обоих случаях погрешность определения составляет $\pm 1 \%$ (см. таблицу). Бо́льшие расхождения определения ОВ в кукерсите по дериватограммам и по

Состав горючего сланца по дериватограммам

\begin{tabular}{|c|c|c|c|c|c|c|c|c|}
\hline \multirow{3}{*}{$\begin{array}{c}\text { Продукт } \\
\text { и его } \\
\text { влияние }\end{array}$} & \multirow{3}{*}{$\begin{array}{l}\text { Чувстви- } \\
\text { тельность } \\
\text { ДТА }\end{array}$} & \multicolumn{6}{|c|}{ Содержание, \% } & \multirow{3}{*}{$\begin{array}{c}\text { Содер- } \\
\text { жание } \\
\text { ОВ по уд. } \\
\text { весу, \% }\end{array}$} \\
\hline & & \multirow{2}{*}{$\begin{array}{l}\text { Гипро- } \\
\text { скопи- } \\
\text { ческая } \\
\text { вода }\end{array}$} & \multirow{2}{*}{$\begin{array}{l}\text { OB } \\
\text { по ТГ }\end{array}$} & \multicolumn{2}{|c|}{ Карбонаты } & \multicolumn{2}{|c|}{$\begin{array}{c}\text { Tерригенный } \\
\text { материал }\end{array}$} & \\
\hline & & & & $\mathrm{CO}_{2}$ & $\begin{array}{l}\text { в перес- } \\
\text { чете на } \\
\mathrm{CaCO}_{3}\end{array}$ & $\mathrm{FeS}_{2}$ & $\begin{array}{l}\text { сили- } \\
\text { каты }\end{array}$ & \\
\hline
\end{tabular}

Исходный сланец Флотац. конц. $1 / 30$ Флотац. остаток

$\begin{array}{llllll}6,7 & 30,1 & 74,0 & 6,0 & 5,4 & 8,0\end{array}$


удельному весу обусловлены, по-видимому, тем, что в исходном кукерсите содержится пирит, а также гидросиликаты с конституционной водой, которые разлагаются в том же интервале температур и покрываются эффектами ОВ.

На кривых ДТА (рисунок, $A, B$, кривая 1 ) появляется эндотермический эффект с макснмумом при $750^{\circ}, 760^{\circ}$, вызванный разложением карбонатов. По кривым ТГ можно установить количество $\mathrm{CO}_{2}$ разложения карбонатов.

При помощи дериватограмм оказывается возможным определить основной вещественный состав горючего сланца-кукерсита и его продуктов обогащения. По кривым ТГ определяется содержание гигроскопической воды, ОВ, карбонатного $\mathrm{CO}_{2}$, а при небольших количествах ОВ - и содержание пирита.

\section{ЛИ Т Е Р А Т У Р А}

1. Т орп ан В. К. О химическом и минералогическом составе пластов и пропластов кукерсита. - Тр. Таллинск. политехн. ин-та, сер. А, № 57. Сб. статей по химии и технологии горючего сланца. с. $22-31$.

2. Л уцков ск а Н. Л., К а заков Е. И. Комплексное термографическое и химическое исследование эстонского сланца-кукерсита. - Изв. АН ЭССР, сер. физ.мат. и техн. н., 1956 , т. 5 , № 2, с. $129-139$.

3. Дил акторский Н. Л., Кир рет О. Г., Эйз ен Ю. И. Термический анализ горючего сланца-кукерсита. - Изв. АН ЭССР, сер. физ.-мат. и техн. н., 1953, т. 2 , № 2 , c. $130-133$.

4. Grassely, Gy., Hetén yi, M., A g ócs, M. Contributions to the alkaline permanganate oxidation of the kerogen, lignite and peat. - Acta Mineral.-Petrograph., 1973, v. $21, \mathrm{~N} \mathrm{1,} \mathrm{p.} \mathrm{55-71.}$

Ннститут химии

Академии наук Эстонской ССР
Поступила в редакцию $21 / \mathrm{XI} 1977$ 